\title{
Baitulmal from the accounting perspective
}

\begin{abstract}
The house of money and wealth or in Arabic term as Byt al-mal (Baitulmal) is one of the most powerful institution to eradicate poverty of muslim community during the era of Prophet (peace be upon Him) and His companions. Bayt al Mal was the department that dealt with the revenues and all other economic matters of the state and it was utilizes for various purposes. This study is embark with the intention to explore Baitulmal from the perspective of accounting, since the major functions of Baitulmal are very closely related to accounting. It is concerning the management of funds and internal control of revenue and expenditure of Baitulmal. The findings from the google scholar search on the title indicate that the study on 'Baitulmal from the accounting perspectives' is scare thus, need to be further explored.
\end{abstract}

Volume 4 Issue 6 - 2019

\author{
Norhanizah Johari \\ Faculty of Management and Muamalah, Kolej Universiti Islam \\ Antarabangsa Selangor, Malaysia
}

Correspondence: Norhanizah Johari, Faculty of Management and Muamalah, Kolej Universiti Islam Antarabangsa Selangor, Malaysia, Email norhanzah@kuis.edu.my

Received: November II, 2019 | Published: December 19, 2019

Keyword: Baitulmal, house of money and wealth, sustainable economy, community, social finance

\section{Introduction}

Bayt al-mal in Arabic term can be translated as "House of Money" or "House of Wealth." In early days of Islam the word "bayt mal almuslimin' or 'bayt mal-Allah' was used to refer to the building or the place where the moveable public properties of Islamic state were stored, until these are disbursed for respective purpose, such as war booties, fifth of war spoils and the like. ${ }^{1}$ Due to emergence in the role and functions of bayt al mal, the usage of the word 'bayt al-mal'was evolved where it refers to the institution or body that owns the public properties of the Muslims. ${ }^{1}$ In the later period, the Bayt al-Māl acts as a treasury complemented with the task of planning and distributing society's wealth in the whole socio-economic and political set-up of a nation. ${ }^{2}$ Historically, Bayt al Mal was not established since the era of Prophet Yusuf and the meaning of the text in verse 55 does not mean that it is established since that time. It was existed since 1000 year before the prophet Yusuf under the ancient Egyptian name prhedjm which means house of treasury or house of silver. There was supervisor for this office. The prophet Yusuf asked to be appointed in this job. The Prophet Yusuf distributed the property of Bayt al Mal to the needy during their difficult times. ${ }^{3}$ During the time of the Prophet Muhammad (peace be upon Him) and His Companions, the Bayt al Mal was initially for the purpose to administer the wealth of the state which was acquired through war, where Islam and Muslims life were concentrated in Makkah and Madinah. This is not only the source of Bayt al Mal. There are Zakat, abscess, tribute, booty, loyalty, and endowments. Its existence was hence not quite noticeable due to the life which was not quite complex at that time. The acquired property including zakat collection was immediately distributed without any delay. ${ }^{4}$ The Bayt al Mal was formally established during the second Caliph, Umar al-Khattab and it functions was to be in golden era during the period of Umar Abdul 'Aziz, where the good practice of management and governance exercised lead to stability of the society in that era. ${ }^{3}$ In the time of Umar, money came in larger quantities and he allowed salaries to men fighting in the army. Umar summoned a meeting of his Consultative Assembly and sought the opinion of the Companions about the disposal of the money. After consulting the Companions Umar decided to establish the Central Treasury at Madinah. A separate Accounts Department was also set up and it was required to maintain record of all that was spent. Later provincial treasuries were set up in the provinces. After meeting the local expenditure the provincial treasuries were required to remit the surplus amount to the central treasury at Madinah.

From the history recorded Bayt al Mal was the department that dealt with the revenues and all other economic matters of the state. It was a financial institution responsible for the administration of taxes in Islamic states, particularly in the early Islamic Caliphate. It served as a royal treasury for the caliphs and sultans, managing personal finances and government expenditures. Further, it administered distributions of zakat revenues for public works. In Malaysia, the current function of Bayt al Mal or Baitulmal is not just a social institution, but it may works as microfinance institution, to makes the role of Baitulmal more important and meaningful if both of the functions are strengthened. ${ }^{5}$ Baitulmal should rightfully be placed in a high position within the country's administrative system, but in Malaysia its role is limited and subject to the State Islamic Religious Council. ${ }^{6}$ This study is embark with the intention to explore Baitulmal from the perspective of accounting. Since the major functions of Baitulmal as the house of money and wealth as defined in Arabic, thus the function and role of Baitulmal are very closely related to monetary and the management of revenue and expenditure of Baitulmal. Due to most of Baitulmal research conducted are from the anthropology perspective, this study will be a volume-added to scarce literature in the accounting studies on Baitulmal, Thus, this study is conducted with the objectives of:

1. To identify number of previous studies on 'Baitulmal from the accounting perspectives' recorded by the google scholars.

2. To explore the area of 'Baitulmal studies from the accounting perspectives' recorded by the google scholars.

\section{Methods of study}

This preliminary study is conducted using the google scholar search engine to trace the number of results recorded by the google scholars with the full keyword of 'Baitulmal from the Accounting Perspectives'. This study sets 5-year duration of studies on Baitulmal from the accounting perspectives since 2015 until 2019 which was accessed on 9 November 2019. All the research titles and contents with the full keyword 'Baitulmal' were reviewed and recorded not limited to the area of accounting only, but include other area of study for instance; waqf, zakat, and sadaqa. Further screening was done 
to select only studies with the full keywords of 'Baitulmal' only, excluding any partial keywords of 'Baitulmal'. The results of findings were manually tabulated and categorized into the accounting study based on the area of accounting identified.

\section{Findings and discussion}

Based on the review and screening conducted, it was found that not all the studies on 'Baitulmal from the accounting perspectives' is related to the area of accounting only. The search captures all the full and partial keywords of 'Baitulmal from the accounting perspectives' in any area of studies not limited to accounting but also cover other areas such as waqf, zakat, sadaqa, management, governance, finance and economics. The results were tabulated in Table 1. Based on the results tabulated in Table 1, it was found that there were 170 studies recorded for research titles related to Baitulmal. The search used of a full keyword of 'Baitulmal from the accounting perspectives' for duration of 5 years (2015-2019). The findings indicate that the study on Baitulmal from the accounting perspectives need to be further explored in order to empower the role and functions of Baitulmal, as it was used to be in the golden era of Prophet Yusuf and Prophet Muhammad (peace is upon Him) and His companions. Through proper management and internal control of Baitulmal funds, it would be able to eradicate poverty crisis of a country besides promoting sound human values and principles that takes into account the numerous benefits and virtues offered to the human beings and socio economics of a community. ${ }^{7-10}$

Table I The results of studies for baitulmal from the accounting perspectives

\begin{tabular}{lll}
\hline No. Research objectives & Results & $\begin{array}{l}(2015-2019)-170 \text { results of search for 'Baitulmal from th } \\
\text { perspectives'. } \\
(2019)-27 \text { results of search for 'Baitulmal from the accounti } \\
\text { perspectives'. }\end{array}$ \\
$\begin{array}{ll}\text { To identify number of previous studies on 'Baitulmal } \\
\text { from the accounting perspectives' as recorded from } \\
\text { the google scholars search. }\end{array}$ & $\begin{array}{l}(2018)-28 \text { results were recorded by the same searched } \\
\text { I }\end{array}$ & $(2016)-27$ results were recorded by the same searched \\
& $(2015)-40$ results were recorded by the same searched
\end{tabular}

\section{Conclusion}

From the results and discussions in the previous section, we can conclude that the study on Baitulmal from the accounting perspectives is another grey area to be explored. Most of recent studies are emphasizing on the anthropology perspective of Baitulmal per se. This grey area need to be further explored particularly but not limited to the accounting areas i.e. financial reporting, auditing, ethics and accountability, management, social finance, economic, legal and information technology besides the historical development of Baitumal. Furthermore, the potential studies could cover various contexts of studies-local, global, regional, segmental, interval and the like. The spirit of spreading the benefits from Baitulmal fund should be well-preserved even in advances of technology and digitization.

\section{Acknowledgments}

None.

\section{Funding}

None.

\section{Conflicts of interest}

Author declares that there is no conflict of interest.

\section{References}

1. Rahman MH. Bayt Al-Mal And Its Role In Economic Development: A Contemporary Study. Turkish Journal of Islamic Economics. 2015;2(2):21-44.
2. Namazi M. Bayt al-Mal and Distribution of Zakah. Ahlul Bayt World Assembly. 2010;11(2).

3. Abdul Halim LAH. Administration of Baitulmal of Federal Territories: Its Practices and Chanllenges. Malasia: Master Thesis, IIUM; 2014.

4. Abdullah MA. The Entitlement Of The Bayt Al-Mal To A Muslim Praepositus' Estates; An Analysis On The Right Of A Muslim To Bequeath Without Obtaining A Consent From The Bayt Al-Mal. International Journal of Social Sciences And Humanity Studies. 2012;4(1):1309-8063.

5. Possumah BT, Ismail AG. Baitul Mal and Legal Constraint: Public Wealth Management in Malaysian Context, International Journal of Academic Research in Business and Social Sciences. 2012;2(11).

6. Ahmad MY, Mohamed NH, Jamsari EA, et al. Baitulmal's Potential as Trustee for Unclaimed Moneys of Muslims. IJCIET. 2017;8(12):593-599.

7. Dahlan ARA, Mohd Suhaili NS, Khalid K, et al. Islamic Transformation Centre-Leveraging On E-Baitulmal through the Quadruple Helix Model (QHM) Collaboration. International Journal of Management and Commerce Innovations. 2015;3(1):58-66.

8. Abu Bakar M. Concept of Revenue, Expenses and Liabilities in Accounting for Zakat, Waqf and Baitulmal in Malaysia: An Analysis from Shariah Perspective. International Journal of Zakat. 2018;1-16.

9. Mohd Nor R. Baitulmal Management During the Reign of Caliph Umar Ibn Abdul Aziz. Open Journal of Social Sciences. 2015;3:90-94.

10. Utami S, Firmansyah F, Cakhyaneu A. Baitul Maal Wat Tamwil as an Islamic Financial Inclusion Institution Model towards a Sustainable Development. 1st UPI International Conference on Sociology Education (UPI ICSE 2015); 2016. 